\title{
PENGARUH RASIO DAGING AYAM BROILER (Gallus domesticus) DENGAN JAMUR MERANG (Volvariella volvacea S.) TERHADAP KARAKTERISTIK TUM AYAM
}

\section{The Effect of Ratio of Broiler Chicken Meat with Straw Mushrooms on the Characteristics of Chicken Tum}

\author{
Kiki Iqlima Rahmadaeni ${ }^{1)}$, I Ketut Suter ${ }^{2)}$, I Made Sugitha ${ }^{2)}$ \\ ${ }^{1}$ Mahasiswa Program Studi Ilmu dan Teknologi Pangan, Fakultas Teknologi Pertanian, Universitas Udayana \\ ${ }^{2}$ Dosen Program Studi Ilmu dan Teknologi Pangan, Fakultas Teknologi Pertanian, Universitas Udayana \\ Kampus Bukit Jimbaran, Badung-Bali
}

\begin{abstract}
The aims of this research was to determine the effect of the ratio of broiler chicken meat with straw mushroom to the characteristics of chicken tum and to determine the right comparison between chicken meat and straw mushroom that can produce chicken tum with the best characteristics. This study used a Completely Randomized Design with a treatment ratio between meat of broiled chicken and mushroom 100:0, 90:10, 80:20, 70:30, 60:40, and 50:50. This treatment was repeated 3 times so that was obtained as many as 18. Experimental units data were analyzed with Analysis of Variance (ANOVA) and then followed by Duncan's test. The ratio of broiler chicken and straw mushroom significantly influenced texture, color hedonik, fat content and crude fiber content. Not significant effect to taste hedonic, flavor hedonic, overall hedonic and cholesterol content. The best treatment was 50\% of broiler chicken meat with $50 \%$ straw mushroom, with the characteristic of chicken tum the analysis of fat content $9,33 \%$, crude fiber content $11,16 \%$, cholesterol content $2,22 \%$, the texture, color, taste, flavor and overall were acceptance.
\end{abstract}

Keyword: chicken tum, straw mushrooms, fiber contetht, fat contetnt.

\section{PENDAHULUAN}

Makanan tradisional adalah makanan yang dikonsumsi oleh golongan etnik dan wilayah spesifik. Bahan yang digunakan berasal dari daerah setempat dan diolah berdasarkan resep secara turun temurun serta makanan yang dihasilkan sesuai dengan selera masyarakat (Hadisantosa, 1993). Klasifikasi makanan dalam budaya Bali dibagi menjadi dua kategori pokok yaitu makanan pokok (nasi, sayur-mayur, lauk-pauk, sambal dan minuman) dan makanan sampingan. Kekhasan suatu makanan lebih banyak dijumpai dalam unsur lauk pauk dan sambal, sehingga dapat dibedakan antara satu daerah dengan daerah lainnya (Panji, 1985). Makanan tradisional Bali dapat dikelompokkan menjadi 4 jenis yaitu olaholahan kering seperti sate, olah-olahan basah seperti lawar, timbungan dan brengkes, olaholahan cair seperti komoh, dan gerang asem serta olah-olahan yang dimasak utuh seperti betutu dan be guling (Anon., 1985 dalam Yusa dan Suter, 2014).

Salah satu makanan tradisional Bali yang termasuk kelompok olahan basah adalah tum. Tum berarti dibungkus dengan sejenis daun (biasanya daun pisang). Sampai saat ini tum masih sering dikonsumsi oleh masyarakat Bali. Proses memasak tum menggunakan teknik pengukusan. Salah satu bahan yang sering digunakan dalam pembuatan tum adalah daging ayam broiler. Proses pembuatan tum adalah dengan menambahkan bumbu (base) genep gede yang dicincang (dirajang) dan bumbu tambahan base embe. Campuran dari base pada bahan utama yang digunakan memberikan rasa dan aroma khas pada tum.

Banyak orang saat ini yang mulai mengurangi konsumsi daging untuk menghindari kolesterol yang dapat menyebabkan penyakit jantung maupun darah tinggi, sehingga sekarang orang beralih ke makanan yang berasal dari nabati

\footnotetext{
*Korespondensi Penulis:

E-mail: kikiiqlimaa@gmail.com ${ }^{1)}$
} 
(vegetarian). Penambahkan bahan lain pada tum ayam dapat menurunkan kadar lemak pada tum ayam, sehingga dapat mengurangi kadar kolesterol juga. Bahan pangan lain yang dapat dijadikan sebagai bahan campuran dalam tum dengan tidak mengurangi mutu tum ayam adalah jamur merang (Volvariella volvaceae). Jamur merang merupakan sumber protein dan mineral yang baik dengan kandungan kalium dan fosfor tinggi sedangkan kandungan lemaknya rendah. Jamur merang adalah salah satu jenis jamur pangan yang memiliki kandungan serat cukup tinggi dan memiliki rasa yang khas dengan tekstur yang baik serta nilai gizi yang cukup lengkap (Tranggono et al., 1983). Harga Jamur merang juga lebih stabil dan lebih murah dibandingkan dengan harga daging ayam broiler.

Jamur merang per $100 \mathrm{~g}$ bahan segar mengandung energi 39,0 kalori, protein 3,8 g, lemak 0,6 g, serat kasar 1,2 g, abu 1,0 g dan total karbohidrat $6,0 \mathrm{~g}$. Purwanto et al., (2015) melaporkan bahwa kandungan serat kasar semakin meningkat seiring dengan meningkatnya penggunaan jamur merang pada produk yang dihasilkan. Anggraeni (2017) juga melaporkan penambahan jamur tiram pada tum ayam menghasilkan tum ayam dengan karakteristik terbaik dengan substitusi daging ayam broiler 60\%: 40\% jamur tiram putih. Berdasarkan penelitian sebelumnya tersebut, maka jamur merang sangat potensial untuk dijadikan bahan baku pada produk tum ayam, sehingga tum ayam dengan jamur merang diharapkan menjadi salah satu lauk pauk yang mengandung serat tinggi dan rendah kolesterol. Tujuan dari penelitian ini adalah untuk mengetahui pengaruh rasio daging ayam broiler dengan jamur merang terhadap karakteristik tum ayam dan untuk mengetahui rasio antara daging ayam broiler dengan jamur merang yang tepat untuk menghasilkan tum ayam dengan karakteristik terbaik.

\section{METODE PENELITIAN}

\section{Tempat dan Waktu}

Penelitian ini dilaksanakan di Laboratorium Pengolahan Pangan, Laboratorium Analisis Pangan, Laboratorium Rekayasa Proses dan Pengendalian Mutu Fakultas Teknologi Pertanian Universitas Udayana. Penelitian ini dilakukan pada bulan AgustusOktober 2018

\section{Bahan dan Alat}

Bahan yang digunakan pada proses pengolahan dan analisis kimia adalah bahan utama terdiri dari daging ayam broiler dari pasar tradisional di daerah Jimbaran, jamur merang didapat dari petani jamur merang di Malang, bumbu (base) genep gede yang terdiri dari bawang merah, bawang putih, cabai rawit, lengkuas, jahe, kunyit, kencur, ketumbar, daun salam, merica, sereh, terasi, kemiri, biji pala, cengkeh, daun salam, cabai puyang (tabya bun), garam, base embe yaitu bawang merah, bawang putih, dan cabai rawit, serta bahan untuk analisis proksimat adalah aquades, tablet kjeldahl, $\mathrm{H}_{2} \mathrm{SO}_{4}$, $\mathrm{NaOH}, \mathrm{HCl}$, indikator phenolphtalein (PP), heksan teknis.

Alat yang digunakan pada proses pengolahan terdiri dari timbangan analitik, talenan, pisau, waskom, panci kukus, blender (miyako), kompor gas (Rinnai) dan alat yang digunakan untuk analisis kimia yaitu oven (Labo DO 225), kertas saring, kertas whatman no. 42, labu erlenmeyer (pyrex), pipet volume (Pyrex), pipet tetes, pompa karet, labu kjeldahl, vortex (Maxi Mix II Type 367000), waterbath, aluminium foil, lumpang, desikator, biuret, pinset, muffle, soxhlet, pendingin balik, destilator, gelas ukur (Pyrex), cawan porselain, botol timbang, timbangan analitik (Shimadzu ATY224), corong, spektrofotometer UV -Vis (Genesys 10s $U v$-Vis), rak tabung. 


\section{Rancangan Percobaan}

Rancangan yang digunakan pada penelitian ini adalah Rancangan Acak Lengkap (RAL) yang terdiri dari 6 perlakuan, yaitu rasio daging ayam broiler dengan jamur merang. Perlakuan diulang sebanyak 3 kali ulangan sehingga diperoleh 18 unit percobaan.

Perlakuan rasio daging ayam boiler dengan jamur merang sebagai berikut :

$\mathrm{P0}=$ daging ayam boiler $100 \%$ : jamur merang $0 \%$

$\mathrm{P} 1=$ daging ayam boiler $90 \%$ : jamur merang $10 \%$

$\mathrm{P} 2$ = daging ayam boiler $80 \%$ : jamur merang $20 \%$

P3 = daging ayam boiler $70 \%$ : jamur merang $30 \%$

$\mathrm{P} 4=$ daging ayam boiler $60 \%$ : jamur merang $40 \%$

P5 = daging ayam boiler 50\% : jamur merang $50 \%$

Data yang diperoleh dianalisis dengan sidik ragam, apabila perlakuan berpengaruh terhadap variabel yang diamati, maka dilakukan dengan uji Duncan (Gomez dan Gomez, 1995).

\section{Pelaksanaan Penelitian}

Proses pembuatan tum ayam dilakukan sesuai dengan hasil wawancara dengan Diarta tahun 2018 di daerah Ungasan, Jimbaran, sebagai berikut :

\section{Persiapan bahan baku}

Bahan baku utama yang digunakan pada pembutan tum adalah ayam boiler dan jamur merang. Kedua bahan tersebut kemudian disortasi dan dicuci. Daging ayam broiler yang telah dicuci diambil bagian dagingnya saja kemudian dicincang halus. Jamur merang sebelumnya diberikan perlakuan blansir dengan perebusan pada suhu $80^{\circ} \mathrm{C}$ selama 5 menit. Jamur merang yang telah diblansir kemudian dicincang halus. Bahan-bahan yang telah dicincang kemudian ditimbang sesuai dengan formulasi.

\section{Persiapan bumbu}

Bahan-bahan yang digunakan sebagai bumbu dibersihkan kemudian ditimbang sesuai dengan formulasi. Bumbu yang digunakan pada pembuatan tum terdiri dari dua jenis bumbu, yaitu base genap gede yang terdiri dari bawang merah, bawang putih, cabai rawit, lengkuas, jahe, kunyit, sereh, daun salam, daun jintan dan kencur yang dipotong kecil-kecil, terasi, merica, ketumbar, cengkeh, biji pala, lada hitam dan garam dicampur menjadi satu kemudian dihaluskan dengan blender. Bumbu tambahan yang digunakan pada pembuatan tum adalah base embe yaitu bawang merah, bawang putih dan cabai yang dicincang halus. Komposisi bumbu base genep gede dan base embe dapat dilihat pada Tabel 1 dan 2 .

\section{Pembuatan tum}

Pertama bahan baku yang telah disiapkan dicampur dengan base genep gede yang telah dihaluskan dan ditetapkan takarannya. Adonan kemudian diaduk hingga tercampur rata. Adonan bahan dengan base genep gede yang telah tercampur kemudian ditambahkan kembali dengan base embe yang yang telah ditetapkan takarannya. Setiap 1 bungkus tum diisi dengan 25 gram adonan tum. Tum dibungkus dengan daun pisang yang sebelumnya telah dibersihkan. Batang lidi yang telah dipotong pendek digunakan untuk menjepit daun pisang pada proses membungkus tum. Tum yang telah dibungkus kemudian dikukus didalam panci pengukus selama 35 menit. Komposisi bahan-bahan yang digunakan dalam pembuatan tum dapat dilihat Tabel 3 .

\section{Variabel yang Diamati}

Variabel yang dianalisis adalah kadar lemak dengan metode soxhlet (Sudarmadji et al., 1997), kadar serat kasar dengan metode hidrolisis asam dan basa (Sudarmadji et al., 1997), kadar kolesterol dengan metode Lieberman Burchard (Kleiner Dotti, 1962), dan sifat organoleptik yang meliputi tekstur, 
warna, rasa, aroma dan penerimaan keseluruhan pada tum ayam. Variabel yang telah dianalisis kemudian dilakukan analisis ragam, sehingga menghasilkan tum dengan karakteristik terbaik. Tum dengan karakteristik terbaik selanjutnya dianalisis proksimat untuk mengetahui kandungan gizi lainnya. Variabel yang dianalisis pada analisis proksimat adalah kadar air dengan metode pengeringan (Sudarmaji et al., 1997), kadar abu dengan metode pengabuan (Sudarmaji et al., 1997), kadar protein dengan metode Mikro Kjeldahl (Sudarmadji et al., 1997), serta kadar karbohi drat (Carbohidrat by different) (Sudarmadji et al., 1997).

Tabel 1. Bahan-bahan penyusun base genep gede untuk $100 \mathrm{~g}$ tum ayam (Diarta, 2018)

\begin{tabular}{|c|c|c|c|c|c|c|}
\hline Bahan & & & & Persen & $(\%)$ & \\
\hline Bawang Merah & & & & & & \\
\hline Bawang Putih & & & & & & \\
\hline Cabai Rawit & & & & & & \\
\hline Lengkuas (g) & & & & & & \\
\hline Jahe $(g)$ & & & & & & \\
\hline Kunyit (g) & & & & & & \\
\hline Ketumbar (g) & & & & & & \\
\hline $\operatorname{Kemiri}(\mathrm{g})$ & & & & & & \\
\hline Daun Salam (g) & & & & & & \\
\hline Merica $(g)$ & & & & & & \\
\hline Sereh $(g)$ & & & & & & \\
\hline Kencur (g) & & & & & & \\
\hline Garam (g) & & & & & & \\
\hline Terasi (g) & & & & & & \\
\hline Lada hitam (g) & & & & & & \\
\hline Biji pala $(g)$ & & & & & & \\
\hline Cengkeh (g) & & & & & & \\
\hline Cabai Puyang (g) & & & & & & \\
\hline Daun Jintan $(\mathrm{g})$ & & & & & & \\
\hline Total Base Genep (g) & & & & & & \\
\hline Tabel 2. Bahan-bahan pe & & 1 & 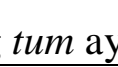 & Diarta, & & \\
\hline Bahan & & & & Persen & $(\%)$ & \\
\hline Bawang Merah (g) & & & & & & \\
\hline Bawang Putih (g) & & & & & & \\
\hline Cabai Rawit (g) & & & & & & \\
\hline Total base embe (g) & & & & & & \\
\hline Tabel 3. Formula tum (D & 018) & & & & & \\
\hline & & & & & & \\
\hline Bahan & $\mathrm{P}_{0}$ & $\mathrm{P}_{1}$ & $\mathrm{P}_{2}$ & $\mathrm{P}_{3}$ & $\mathrm{P}_{4}$ & $\mathrm{P}_{5}$ \\
\hline Daging Ayam Broiler (\%) & 100 & 90 & 80 & 70 & 60 & 50 \\
\hline Jamur Merang (\%) & 0 & 10 & 20 & 30 & 40 & 50 \\
\hline Base genep (\%) & 25,08 & 25,08 & 25,08 & 25,08 & 25,08 & 25,08 \\
\hline Base embe (\%) & 9 & 9 & 9 & 9 & 9 & 9 \\
\hline
\end{tabular}




\section{HASIL DAN PEMBAHASAN}

\section{Analisis Bahan Baku}

Nilai rata-rata hasil analisis kadar air, Kadar abu, kadar protein, kadar lemak, kadar karbohidrat, kadar serat kasar dan kadar kolesterol dari daging ayam broiler segar dan jamur merang segar yang digunakan dapat dilihat pada Tabel 4. sangat nyata sangat nyata $(\mathrm{P}<0,01)$ terhadap kadar lemak tum. Tabel 5 menunjukkan kadar lemak pada tum berkisar antara 14,24\% sampai dengan 9,09\%. Kadar lemak tertinggi diperoleh dari perlakuan $100 \%$ daging ayam broiler dengan $0 \%$ jamur merang (P0) yaitu $14,23 \%$, kadar lemak terendah diperoleh perlakuan $50 \%$ daging ayam broiler dengan $50 \%$ jamur merang (P5) yaitu $9,09 \%$. Hasil

Tabel 4. Nilai rata-rata hasil analisis kadar air, kadar abu, kadar protein, kadar lemak, kadar karbohidrat, kadar serat kasar dan kadar kolesterol dari bahan baku.

\begin{tabular}{lll}
\hline Variabel uji & Daging Ayam Broiler & Jamur Merang \\
\hline Air $(\%)$ & $66,32 \pm 0,50$ & $88,61 \pm 0,03$ \\
Abu (\%) & $1,23 \pm 0,00$ & $0,99 \pm 0,09$ \\
Protein $(\%)$ & $19,54 \pm 0,24$ & $7,56 \pm 0,60$ \\
Lemak (\%) & $12,12 \pm 0,50$ & $0,52 \pm 0,03$ \\
Karbohidrat (\%) & $0,79 \pm 0,71$ & $2,32 \pm 0,61$ \\
Serat Kasar (\%) & $4,68 \pm 0,65$ & $29,36 \pm 0,57$ \\
Kolesterol (\%) & $0,55 \pm 0,01$ & $0,09 \pm 0,02$ \\
\hline
\end{tabular}

Keterangan: Nilai rata-rata dengan \pm standar deviasi.

Daging ayam broiler segar bagian dada memiliki kadar abu $1,23 \%$, kadar protein $19,54 \%$, kadar lemak 12,12\%, dan kadar kolesterol 2,77\% yang lebih tinggi, sedangkan kadar air 66,32\%, kadar karbohidrat $0,79 \%$ dan serat kasar $4,68 \%$ lebih kecil dibandingkan jamur merang.

Jamur merang segar memiliki kadar air $88,61 \%$, kadar karbohidrat 2,32\% dan kadar serat kasar 29,36\% lebih tinggi, sedangkan kandungan kadar abu 0,99\%, kadar protein $7,56 \%$, kadar lemak $0,52 \%$, dan kadar kolesterol $0,47 \%$, lebih rendah dibandingkan daging ayam broiler.

\section{Karakteristik Tum}

Nilai rata-rata hasil analisis kadar lemak, kadar serat kasar dan kadar kolesterol pada tum ayam dengan perbandingan antara daging ayam broiler dengan jamur merang dapat dilihat pada Tabel 5.

\section{Kadar Lemak}

Hasil analisis ragam kadar lemak menunjukkan bahwa rasio daging ayam yaitu analisis menunjukkan semakin banyak penggunaan jamur merang menyebabkan kadar lemak pada tum semakin rendah. Penurunan kadar lemak ini disebabkan karena kadar lemak jamur merang lebih rendah dibandingkan kadar lemak daging ayam broiler. Kadar lemak pada jamur merang segar adalah $0,52 \%$, sedangkan kadar lemak pada daging ayam broiler segar bagian dada sebesar $12,12 \%$.

Menurut Lawrie (1995) proses pemasakan/pengolahan daging ayam broiler, terutama pada pengukusan, yaitu pengolahan makanan dengan uap air mendidih, dapat mempengaruhi keadaan daging yang dimasak yang berarti mempengaruhi kandungan zatzat makanan yang terkandung di dalamnya, termasuk kadar lemak. Dhanapal et al., (2012) menyatakan bahwa penyusutan kadar lemak yang telah mengalami proses pengukusan terutama disebabkan oleh hilangnya cairan jaringan selama proses pemasakan. Mengkonsumsi makanan rendah lemak dan membatasi asupan makanan yang mengandung lemak jenuh dan lemak trans 
dapat mencegah terjadinya obesitas yang dapat menjadi faktor pemicu timbulnya berbagai macam penyakit, mulai dari diabetes, jantung hingga stroke (Anon., 2016).

\section{Kadar Serat Kasar}

Hasil analisis ragam pada serat kasar menunjukkan bahwa rasio daging ayam broiler dengan jamur merang berpengaruh sangat nyata $(\mathrm{P}<0,01)$ terhadap kadar serat kasar tum. Tabel 9 menunjukkan kadar serat kasar pada tum berkisar antara 4,97\% sampai dengan $11,16 \%$. Kadar serat kasar tertinggi diperoleh dari perlakuan $50 \%$ daging ayam broiler dengan $50 \%$ jamur merang (P5) yaitu $11,16 \%$, kadar serat kasar terendah diperoleh perlakuan $100 \%$ daging ayam broiler dengan $0 \%$ jamur merang (P0) yaitu 4,97\%.

Kadar serat kasar pada tum ayam dipengaruhi oleh kadar serat kasar bahan baku yang digunakan. Semakin banyak penambahan jamur merang pada tum menyebabkan kadar serat kasar semakin meningkat. Hal ini disebabkan kadar serat kasar pada jamur merang segar lebih tinggi yaitu 29,36\%, sedangkan kandungan serat kasar pada daging ayam broiler segar bagian dada sebesar 4,68\%. Semakin meningkat penggunaan jamur merang maka semakin meningkat kadar serat kasar tum ayam yang dihasilkan. Hal ini dipengaruhi oleh banyaknya jamur merang yang digunakan dalam pembuatan tum ayam.

Konsumsi serat dapat membantu menurunkan absorpsi lemak dan kolesterol di dalam darah. Kecukupan asupan serat kini dianjurkan semakin tinggi, mengingat banyak manfaat yang menguntungkan untuk kesehatan tubuh, adequate intake (AI) untuk serat makanan sebagai acuan untuk menjaga kesehatan saluran pencernaan dan kesehatan lainnya kini telah dikeluarkan oleh Badan
Kesehatan Internasional. AI untuk serat makanan bagi orang dewasa adalah 20-35 g/hari (Fransisca, 2004). Serat berperan dalam mengendalikan kadar lemak darah termasuk kadar trigliserida darah dengan cara memperlambat absorpsi gula dan mengikat asam empedu, lemak, dan kolesterol serta mengeluarkannya bersama feses (Almatsier, 2009).

\section{Kadar Kolesterol}

Hasil analisis ragam menunjukkan bahwa rasio daging ayam broiler dengan jamur merang berpengaruh sangat nyata $(\mathrm{P}<0,01)$ terhadap kadar kolesterol tum. Tabel 9 menunjukkan kadar kolesterol pada tum berkisar antara 0,69\% sampai dengan 0,4\%. Kadar kolesterol tertinggi diperoleh perlakuan $100 \%$ daging ayam broiler dengan $0 \%$ jamur merang. Semakin banyak penambahan jamur merang menyebabkan kadar kolesterol pada tum ayam semakin menurun.

Seringnya mengkonsumsi makanan tinggi lemak menjadi penyebab utama meningkatnya kadar kolesterol total di dalam darah. Hasil penelitian Sulastri et al., (2005) menunjukkan kadar kolesterol akan berkurang seiring dengan rendahnya asupan makanan berlemak. Kadar kolesterol yang melebihi batas normal akan memicu terjadinya proses aterosklerosis. Aterosklerosis merupakan proses terjadinya penyempitan pembuluh darah oleh lemak.

\section{Sifat Sensoris}

Nilai rata-rata hasil evaluasi sensoris tum ayam dengan jamur merang dilakukan dengan uji hedonik terhadap tekstur, warna, rasa, aroma dan penerimaan keseluruhan serta uji skoring terhadap tekstur tum ayam dengan jamur merang yang dapat dilihat pada Tabel 6. 
Tabel 5. Nilai rata-rata hasil kadar lemak, kadar serat kasar dan kadar kolesterol dari tum ayam jamur merang

\begin{tabular}{cccc}
\hline Perlakuan & Lemak $(\%)$ & Serat Kasar $(\%)$ & Kolesterol (\%) \\
\hline P0 & $14,23 \pm 0,35 \mathrm{a}$ & $4,97 \pm 0,19 \mathrm{e}$ & $0,69 \pm 0,01 \mathrm{e}$ \\
P1 & $13,56 \pm 0,12 \mathrm{~b}$ & $5,23 \pm 0,19 \mathrm{e}$ & $0,65 \pm 0,01 \mathrm{~d}$ \\
P2 & $12,74 \pm 0,57 \mathrm{c}$ & $6,54 \pm 0,31 \mathrm{~d}$ & $0,63 \pm 0,01 \mathrm{c}$ \\
P3 & $11,53 \pm 0,17 \mathrm{~d}$ & $8,84 \pm 0,17 \mathrm{c}$ & $0,60 \pm 0,01 \mathrm{bc}$ \\
P4 & $10,67 \pm 0,37 \mathrm{e}$ & $9,99 \pm 0,32 \mathrm{~b}$ & $0,56 \pm 0,02 \mathrm{~b}$ \\
P5 & $9,09 \pm 0,13 \mathrm{f}$ & $11,16 \pm 0,38 \mathrm{a}$ & $0,44 \pm 0,04 \mathrm{a}$ \\
\hline
\end{tabular}

Keterangan: Nilai rata-rata yang diikuti dengan huruf yang berbeda pada kolom yang sama menunjukkan berbeda nyata pada Uji Duncan 0,05 . Nilai rata-rata dengan \pm standar deviasi.

Tabel 6. Nilai rata-rata uji hedonik tekstur, warna, rasa, aroma dan penerimaan keseluruhan serta uji skoring tum ayam dengan jamur merang

\begin{tabular}{ccccccc}
\hline \multirow{2}{*}{ Perlakuan } & \multirow{2}{*}{ Warna } & \multirow{2}{*}{ Aroma } & \multirow{2}{*}{ Rasa } & \multicolumn{2}{c}{ Tekstur } & Penerimaan \\
\cline { 5 - 6 } & & & & Hedonik & Skoring & keseluruhan \\
\hline P0 & $4,60 \pm 0,74 \mathrm{a}$ & $4,93 \pm 0,26 \mathrm{a}$ & $4,73 \pm 0,46 \mathrm{a}$ & $3,67 \pm 1,29 \mathrm{c}$ & $2,80 \pm 1,01 \mathrm{~d}$ & $4,80 \pm 0,41 \mathrm{a}$ \\
P1 & $4,67 \pm 0,62 \mathrm{a}$ & $4,93 \pm 0,26 \mathrm{a}$ & $4,73 \pm 0,46 \mathrm{a}$ & $4,13 \pm 0,74 \mathrm{bc}$ & $3,07 \pm 0,70 \mathrm{~cd}$ & $4,87 \pm 0,35 \mathrm{a}$ \\
P2 & $4,60 \pm 0,51 \mathrm{a}$ & $4,93 \pm 0,26 \mathrm{a}$ & $4,80 \pm 0,41 \mathrm{a}$ & $4,47 \pm 0,74 \mathrm{ba}$ & $3,33 \pm 0,49 \mathrm{bc}$ & $4,93 \pm 0,26 \mathrm{a}$ \\
P3 & $4,73 \pm 0,46 \mathrm{a}$ & $4,87 \pm 0,52 \mathrm{a}$ & $4,80 \pm 0,41 \mathrm{a}$ & $4,73 \pm 0,46 \mathrm{ba}$ & $3,67 \pm 0,72 \mathrm{ab}$ & $4,80 \pm 0,56 \mathrm{a}$ \\
P4 & $3,93 \pm 0,80 \mathrm{~b}$ & $4,87 \pm 0,35 \mathrm{a}$ & $4,93 \pm 0,26 \mathrm{a}$ & $4,60 \pm 0,51 \mathrm{a}$ & $3,80 \pm 0,41 \mathrm{ab}$ & $4,93 \pm 0,26 \mathrm{a}$ \\
P5 & $3,60 \pm 0,74 \mathrm{~b}$ & $4,80 \pm 0,41 \mathrm{a}$ & $4,80 \pm 0,56 \mathrm{a}$ & $4,73 \pm 0,46 \mathrm{a}$ & $4,13 \pm 0,74 \mathrm{a}$ & $4,73 \pm 0,46 \mathrm{a}$ \\
\hline
\end{tabular}

Keterangan :

1) Nilai rata-rata yang diikuti dengan huruf yang berbeda pada kolom yang sama menunjukkan berbeda nyata pada Uji Duncan 0,05 . Nilai rata-rata dengan \pm standar deviasi.

2) Hedonik : $1=$ tidak suka, $2=$ agak tidak suka, $3=$ biasa, $4=$ suka, $5=$ sangat suka

3) Skoring : $1=$ keras. $2=$ agak keras, $3=$ biasa, $4=$ lunak, $5=$ sangat luna

\section{Warna}

Hasil analisis ragam menunjukkan bahwa rasio daging ayam broiler dengan jamur merang adalah berpengaruh sangat nyata $(\mathrm{P}<0,01)$ terhadap warna tum. Tabel 6 menunjukkan bahwa nilai rata-rata kesukaan panelis terhadap warna tum antara 3,60\% (biasa) sampai dengan 4,73\% (agak suka). Nilai rata-rata tertinggi diperoleh perlakuan $70 \%$ daging ayam broiler dengan 30\% jamur merang (P3) yaitu 4,73\% (agak suka), sedangkan nilai rata-rata terendah diperoleh perlakuan $50 \%$ daging ayam broiler dengan $50 \%$ jamur merang (P5) yaitu 3,60\% (biasa).

Menurut Winarno (2002) secara visual faktor warna akan tampil lebih dahulu dan sering kali menentukan nilai suatu produk. Penentuan mutu bahan makanan umumnya bergantung pada warna yang dimilikinya, warna yang tidak menyimpang dari warna yang seharusnya akan memberi kesan penilaian tersendiri oleh panelis (Negara, et al., 2016). L'opez et al., (1992) selama proses pengolahan, jamur merang akan mengalami reaksi pencoklatan dan perubahan tekstur. Selama pemanasan warna daging juga akan berubah secara bertahap dari merah muda menjadi lebih pucat. Perubahan warna tersebut akibat dari jumlah pigmen myoglobin yang teroksidasi menjadi metmyoglobin dan polimerisasi protein (Putri, 2009).

\section{Aroma}

Hasil analisis ragam terhadap aroma tum menunjukkan bahwa rasio daging ayam broiler dengan jamur merang berpengaruh tidak nyata $(\mathrm{P}>0,05)$. Tabel 6 menunjukkan 
bahwa nilai rata-rata kesukaan panelis antara tum. Hal ini menunjukkan panelis menyukai aroma dari tum ayam dengan penambahan jamur merang. Terjadi penurunan pada hasil rata-rata nilai kesukaan panelis terhadap aroma tum ayam namun tidak berbeda signifikan.

Aroma merupakan ciri lain yang penting dalam menilai tingkat penerimaan konsumen terhadap suatu produk pangan. Winarno (1992) mengatakan bahwa uji aroma lebih banyak melibatkan indra penciuman, karena kelezatan suatu makanan sangat ditentukan oleh aroma makanan tersebut dan dapat merupakan salah satu indikator penting dalam menentukan kualitas bahan pangan. Umumnya konsumen akan menyukai bahan pangan jika mempunyai aroma khas yang tidak menyimpang dari aroma normal.

\section{Rasa}

Hasil analisis ragam terhadap rasa tum menunjukkan bahwa rasio daging ayam broiler

bagian dengan jamur merang adalah berpengaruh tidak nyata $(\mathrm{P}>0,05)$. Tabel 6 menunjukkan bahwa nilai rata-rata kesukaan panelis terhadap rasa tum antara $4,73 \%$ (agak suka) sampai dengan 4,93\% (agak suka), hal ini menandakan panelis cukup menyukai tum. Rasa dapat didefinisikan sebagai karakteristik sensori yang diterima oleh indera pengecap manusia ketika makanan dikonsumsi (Meilgaard et al., 1999).

\section{Tekstur}

Hasil analisis ragam menunjukkan bahwa rasio daging ayam broiler bagian dada dengan jamur merang berpengaruh sangat nyata $(\mathrm{P}<0,05)$ terhadap hedonik tekstur tum. Tabel 6 menunjukkan bahwa nilai rata-rata kesukaan panelis terhadap tektur tum antara 4,27 (agak suka) sampai dengan 4,73\% (agak suka). Nilai rata-rata tertinggi pada parameter tesktur diperoleh perlakuan $70 \%$ daging ayam broiler dengan $30 \%$ jamur merang (P3) dan perlakuan $50 \%$ daging ayam broiler dengan
4,97\% sampai dengan 4,80\% terhadap aroma $50 \%$ jamur merang (P5) yaitu 4,73\% (agak suka). Nilai rata-rata terendah pada tekstur diperoleh perlakuan $100 \%$ daging ayam broiler dengan $0 \%$ jamur merang (P0) yaitu $4,27 \%$ (agak suka). Hal ini menunjukkan semakin meningkat persentase jamur merang menyebabkan tekstur tum semakin lunak.

Hasil analisis ragam menunjukkan bahwa rasio daging ayam broiler dengan jamur merang berpengaruh sangat nyata $(\mathrm{P}<0,05)$ terhadap skoring tum. Tabel 10 menunjukkan bahwa nilai rata-rata kesukaan panelis terhadap tekstur tum antara 2,80\% (agak keras) sampai dengan 4,13\% (lunak). Nilai rata-rata tertinggi pada nilai skoring tekstur tum diperoleh perlakuan 50\% daging ayam broiler dengan 50\% jamur merang (P5) yaitu $4,13 \%$ (lunak). Nilai rata-rata terendah pada nilai skoring tekstur tum diperoleh perlakuan $100 \%$ daging ayam broiler dengan $0 \%$ jamur merang (P0) yaitu 2,80\% (agak keras). Hal ini menunjukkan panelis lebih menyukai tekstur yang lebih lunak pada tum ayam.

Peningkatan nilai tektur ini disebabkan karena semakin banyak penambahan jamur merang. Hal ini memperngaruhi nilai skoring tekstur tum yang dihasilkan menjadi lunak. Sudarisman dan Elvina (1996) juga menjelaskan bahwa tekstur dipengaruhi oleh kadar air yang terkandung di dalamnya. Kandungan air pada daging ayam broiler adalah $66,32 \%$ dan kadar air pada jamur merang sebesar $88,61 \%$.

\section{Penerimaan Keseluruhan}

Hasil analisis ragam menunjukkan bahwa rasio daging ayam broiler bagian dada dengan jamur merang berpengaruh tidak nyata $\quad(\mathrm{P}>0,05)$ terhadap penerimaan keseluruhan tum. Tabel 6 menunjukkan nilai rata-rata tingkat kesukaan panelis terhadap penerimaan keseluruhan tum berkisar antara 4,73\% (agak suka) sampai dengan 4,93\% (agak suka). Penilaian keseluruhan tum ayam dipengaruhi seluruh nilai atribut yang diuji. 
Warna yang menarik, aroma yang kuat, bertekstur lunak dan rasa khas tum ayam serta gurih yang menjadi faktor tingkat penilaian keseluruhan dari tum berbasis daging ayam broiler dan jamur merang.

Tum ayam dengan perlakuan terbaik adalah 50\% daging ayam broiler dengan 50\% jamur merang (P5). Tum dengan perlakuan terbaik kemudian dilakukan analisis proksimat untuk mendapatkan nilai gizi lainnya yaitu kadar air, kadar abu, kadar protein, dan kadar karbohidrat. mendapatkan hedonik rasa agak suka, hedonik aroma agak suka dan penerimaan keseluruhan agak suka.

\section{Saran}

Berdasarkan penelitian ini perlakuan terbaik adalah perlakuan $50 \%$ daging ayam broiler dengan $50 \%$ jamur merang, disarankan untuk dilakukan penelitian tum ayam dengan penambahan jamur merang dengan rasio jamur merang diatas $50 \%$.

Tabel 7. Nilai rata-rata analisis kadar air, abu, protein lemak dan karbohidrat pada perlakuan terbaik (P5).

\begin{tabular}{lcc}
\hline & Variabel & Perlakuan terbaik \\
\hline Air (\%) & $77,87 \pm 0,46$ \\
Abu (\%) & $1,27 \pm 0,06$ \\
Protein (\%) & $9,49 \pm 0,36$ \\
Lemak (\%) & $9,09 \pm 0,13$ \\
Karbohidrat (\%) & $2,28 \pm 0,17$ \\
\hline
\end{tabular}

Keterangan: Nilai rata-rata dengan \pm standar deviasi.

nilai gizi lainnya yaitu kadar air, kadar abu, Hasil analisis proksimat pada tum ayam dengan jamur dapat dilihat pada Tabel 7.

\section{KESIMPULAN DAN SARAN}

\section{Kesimpulan}

Berdsarkan dari hasil penelitian dapat disimpulkan sebagai berikut :

1. Rasio daging ayam broiler dengan jamur merang berpengaruh sangat nyata terhadap kadar lemak, kadar serat kasar, tekstur dan hedonik warna, tetapi tidak nyata terhadap kadar kolesterol, rasa, aroma dan penerimaan keseluruhan.

2. Perlakuan terbaik adalah perlakuan $50 \%$ daging ayam broiler dengan $50 \%$ jamur merang (P5), dengan karakteristik tum adalah kadar lemak 9,33\%, kadar serat kasar 11,16\%, kadar kolesterol 0,44\%, kadar air $77,87 \%$, kadar protein 9,50\%, kadar abu $1,27 \%$, kadar karbohidrat
2,28\%, hedonik tekstur agak suka, skoring tekstur agak suka, hedonik warna biasa

\section{DAFTAR PUSTAKA}

Almatsier S. 2009. Prinsip dasar ilmu gizi. PT Gramedia 25. Pustaka Utama, Jakarta

Anggraeni, Ni Putu Widya. 2017. Pengaruh Substitusi Daging Ayam (Gallus domesticus) Dengan Jamur Tiram Putih (Pleurotus ostreatus) Terhadap Karakteristik Tum Ayam. Skripsi. Fakultas Teknologi Pertanian. Universitas Udayana.

Anonimus. 1995. Komposisi Zat Gizi Pangan Indonesia. Departemen Kesehatan Republik Indonesia. Jakarta: Depkes RI.

Dhanapal K, Reddy VS, Naik BB, Venkateswarlu G, Reddy AD, Basu S. 2012. Effect of cooking on physical, biochemical, bacteriological characteristics and fatty acid profile of 
tilapia (Oreochromis mossambicus) fish steaks. Archives of Applied Science Research 4(2): 1142-1149.

Gomez, K.A, dan A.A. Gomez. 1995. Prosedur Statistik untuk Penelitian Pertanian. Edisi Ke-2. Alih bahasa: Endang Sjamsudin dan Justika S. Baharsjah. Univeristas Indonesia (UIPress), Jakarta.

Kleiner I. S \& B. Dotti. 1962. Laboratory Instruction in Biochemistry. $6^{\text {th }} \mathrm{Ed}$. The C. V Mosby Co, New York.

L'opez, N., G. Cuzon., G. Gaxiola., S. G. Taboada., M. Valenzuela., C. Pascual., A. Sanches dan C. Rosas 1992. Physiological, nutritional, and immnunological role of dietary $\beta$ glucan and ascorcic acid 2monophosphate in Litopenaeus vannamei juveniles. Aquaculture 2(24) : 223-243.

Lawrie, R. A. 1995. Ilmu Daging. Edisi 5. UI Press, Jakarta.

Meilgaard M., GV. Civille, and BT Carr. 1999. Sensory Evaluation Techniques. New York: CRC Press.

Purwanto. A., A. Ali., dan N. Herawati. 2015. Kajian Mutu Gizi Bakso Berbasis Daging Sapi Dan Jamur Merang (Volvariella volvaceae). Program Studi Teknologi Hasil Pertanian. Fakultas Pertanian. Universitas Riau, Pekanbaru.

Putri A.F.E. 2009. Sifat fisik dan organoleptik bakso daging sapi pada lama postmortem yang berbeda dengan penambahan karagenan. Skripsi Fakultas Peternakan Institut Pertanian Bogor, Bogor.

Sudarisman T. dan A.R. Elvina. 1996. Petunjuk Memilih Produk Ikan dan
Daging. Cetakan I. PT. Penebar Swadaya, Jakarta.

Sudarmadji, S., B.Haryono dan E.Suhardi, 1997. Prosedur Analisa Untuk Bahan Makanan dan Pertanian Edisi Keempat. Lyberty, Yogyakarta.

Sulastri D., Rahayuningsih S., Purwantyastuti. 2005. Pola asupan lemak, antioksidan, serta hubungannya dengan profil lipid pada laki-laki etnik minangkabau. Majalah Kedokteran Indonesia. 55(2):61-66.

Tranggono, B., Suksmadji dan S. Kanoni. 1983. Beberapa Cara Pengawetan Jamur Merang. Laporan Penelitian. Fakultas Teknologi Pertanian, Universitas Gajah Mada, Yogyakarta.

Winarno FG. 2002. Pangan Gizi, Teknologi, dan Konsumen. Gramedia Pustaka Utama, Jakarta

Winarno, F.G. 1992. Kimia Pangan dan Gizi. PT Gramedia Pustaka Utama, Jakarta.

Yusa, N M. dan I K. Suter. 2014. Pangan Tradisional Khas Gianyar. Udayana University Press, Denpasar. 
